\title{
An analytical method for assessing recharge using groundwater travel time in Dupuit-Forchheimer aquifers
}

\author{
Chesnaux, R. ${ }^{\mathrm{a}, *}$, Santoni, S. ${ }^{\mathrm{b}, \mathrm{c}}$, Garel, E. ${ }^{\mathrm{b}, \mathrm{c}}$ and Huneau, F. ${ }^{\text {b,c }}$ \\ a Université du Québec à Chicoutimi, Centre d'Études sur les Ressources Minérales, \\ Research Group « Risk Resource Water », 555, Bd de l’Université, Chicoutimi (Quebec), \\ G7H 2B1, CANADA. \\ *corresponding author(romain_chesnaux@uqac.ca) \\ ${ }^{\mathrm{b}}$ Université de Corse Pascal Paoli, Faculté des Sciences et Techniques, Laboratoire \\ d'Hydrogéologie, Campus Grimaldi, BP 52, F-20250 Corte, France \\ ${ }^{\mathrm{c}} \mathrm{CNRS}$, UMR 6134, SPE, F-20250 Corte, France
}

\section{Conflict of interest: None}

Key words: Unconfined aquifers, Recharge, Groundwater travel time, Environmental tracers, Analytical method, Bonifacio aquifer

Article Impact Statement: An analytical method is proposed for assessing recharge in unconfined aquifers based on groundwater travel times

\begin{abstract}
An analytical solution to calculate the recharge of unconfined aquifers with DupuitForchheimer type flow conditions is proposed. This solution is derived from an existing closed-form analytical solution initially developed to determine groundwater travel time when the recharge of the aquifer is known. This existing solution has been modified to determine recharge when groundwater travel time is known. An illustration is given with a field case example for the Bonifacio aquifer of the island of Corsica (France), in the Mediterranean. In this aquifer, previously established differences in groundwater residence time between two water samples were determined from anthropogenic
\end{abstract}

This article has been accepted for publication and undergone full peer review but has not been through the copyediting, typesetting, pagination and proofreading process, which may lead to differences between this version and the Version of Record. Please cite this article as doi: $10.1111 /$ gwat.12794 
atmospheric gas (CFCs and $\left.\mathrm{SF}_{6}\right)$ measurements. The time difference is entered into the new analytical solution to determine recharge. The calculations yield a value of average recharge that agrees with the results obtained by several other methods that were presented in previous studies to assess the recharge of the Bonifacio aquifer. Also presented in this study is a sensitivity analysis of the new analytical solution, to quantify the influence of different parameters that control recharge: hydraulic conductivity, effective porosity and the groundwater travel time. This study illustrates how geochemical data can be combined with physical models to measure recharge. Such an approach could be adopted in other homogeneous aquifers worldwide that satisfy DupuitForchheimer type flow conditions.

\section{Introduction}

Constraining aquifer recharge rates is of primary importance for the sustainable management of water resources, but this calculation has generally shown itself to be complicated and the results imprecise. The difficulty in assessing recharge rates lies in the inherent heterogeneity of aquifers as well as the multiple processes which naturally occur during infiltration (de Vries and Simmers 2002; Scanlon et al. 2002; Meixner et al. 2016; Hartmann et al. 2017). A large panel of methods exists for assessing recharge rates in unconfined aquifers (Lerner et al. 1990; Kinzelbach et al. 2002; Scanlon et al. 2002). A realistic estimation of acceptable accuracy and degree of confidence requires the combined use of several different approaches that complement and support each other (Scanlon et al. 2006; Huet et al. 2016). 
Analytical methods can be used to describe groundwater flow conditions and to estimate recharge rates (Chesnaux 2013). This study proposes an analytical approach for assessing recharge which consists of combining two validated techniques, each designed to calculate groundwater travel times in an aquifer. Considering a certain number of assumptions of a steady-state Dupuit-Forchheimer type flow (Dupuit 1863; Forchheimer 1886) in an unconfined aquifer in this study, recharge is estimated by combining the results of two methods for calculating groundwater travel time: a) geochemical agedating using environmental tracers; and b) a physical method using an analytical solution (Chesnaux et al. 2005). The proposed methodology for calculating recharge based on combining the two methods is illustrated with a field study.

The Bonifacio aquifer located in the southern part of the island of Corsica (France) was selected for the field study illustration because its geology and hydrogeological features are well documented (Orsini et al. 2010; Reynaud et al. 2012; Santoni $2016[\mathrm{PhD}$ Thesis]; Santoni et al. 2018). Previous studies have made it possible to accurately assess its groundwater residence times using hydrochemistry, anthropogenic atmospheric gases (CFCs and $\mathrm{SF}_{6}$ ) and strontium isotopes (Santoni et al. 2016a, b).

\section{Field Site Description}

The Bonifacio aquifer is located in the western Mediterranean Sea, in the southern part of the island of Corsica (France). The aquifer consists of a coastal sedimentary Miocene plateau extending over $25 \mathrm{~km}^{2}$ and lying on a granitic depression (Orsini et al. 2010; Reynaud et al. 2012). There are two aquifer levels separated by an aquitard. Figure 1 presents a simplified map of the hydrogeology of the Bonifacio area. The Bonifacio 
unconfined aquifer and its properties have been described in detail in Santoni et al. (2016a,b). It is composed of calcareous sandstones and sandy calcarenites representing a very compacted and hard material with a cemented granular structure; despite this, its effective porosity is rather high at 7\% (Dörfliger et al. 2002). This unconfined aquifer lies on a 50-m thick silty layer that represents the aquitard level in regards to the unconfined aquifer. The 50 to $100 \mathrm{~m}$ thick aquifer is bounded to its sub-horizontal base by the silty aquitard, to the South-West by the Mediterranean Sea (Bonifacio Harbour) and it is elsewhere bounded at its sides by granitic crystalline bedrock outcrops. The hydraulic properties of this aquifer have been characterized during a geophysical survey (Dörfliger et al. 2002); it has been observed that the aquifer can be considered homogeneous. Furthermore, it is favorable to groundwater flow with a hydraulic conductivity comprised between $1.3 \times 10^{-4} \mathrm{~m} / \mathrm{s}$ and $3 \times 10^{-4} \mathrm{~m} / \mathrm{s}$, as determined from pumping tests conducted by Alamy and Chiari (2010).

Finally, Santoni (2016) and Santoni et al. (2018) have shown that groundwater extraction is estimated to comprise only $5 \%$ of the aquifer's total annual recharge and that it is limited and localized in the city of Bonifacio. They have also shown that groundwater extraction does not significantly affect groundwater flow at a regional scale in terms of directions and gradients.

\section{Methods}

\section{Analytical solution for computing groundwater travel times}


The closed-form analytical solution of Chesnaux et al. (2005) is used to calculate advective groundwater travel times in the configuration of a Dupuit-Forchheimer type flow system (Dupuit 1863; Forchheimer 1886; Bear 1972) in an unconfined aquifer (Figure 2).

Equation 1 is the general analytical solution to calculate the travel time of a particle flowing between position $x_{i}$ at the water table to a downgradient position $x$ within an unconfined, horizontal aquifer under uniform surface recharge.

$$
\begin{aligned}
& t(x)=n_{e} \sqrt{\frac{\alpha}{K W}}\left[x \sqrt{\frac{1}{x^{2}}-\frac{1}{\alpha}}-x_{i} \sqrt{\frac{1}{x_{i}^{2}}-\frac{1}{\alpha}}+\ln \left(\frac{\sqrt{\alpha} / x_{i}+\sqrt{\alpha / x_{i}^{2}-1}}{\sqrt{\alpha} / x+\sqrt{\alpha / x^{2}-1}}\right)\right] \\
& \text { with } \alpha=L^{\prime 2}+\frac{K h_{L^{\prime}}^{2}}{W} .
\end{aligned}
$$

where $K$ is the hydraulic conductivity of the aquifer $\left[\mathrm{LT}^{-1}\right], W$ is the aquifer recharge $\left[\mathrm{LT}^{-}\right.$ $\left.{ }^{1}\right], L^{\prime}$ is the length of the aquifer [L], $n_{e}$ is the effective porosity of the porous medium and $h_{L^{\prime}}^{2}$, is the hydraulic head of the constant-head boundary discharge [L].

The analytical solution of Chesnaux et al. (2005) has been verified against numerical modeling. A derived solution for groundwater travel times in a horizontal unconfined aquifer in oceanic islands was established later by Chesnaux and Allen (2008) and has 
been verified against experimental travel time measurements (Stoeckl and Houben 2012). Equation 1 is now extensively used by scientists and practitioners to calculate groundwater travel time (INOWAS, 2017). More recently, the analytical solution was modified to estimate the changes in groundwater travel time in coastal and island aquifers exposed to sea-level rise due to climate change (Chesnaux 2015; Chesnaux 2016).

\section{CFCs and $\mathrm{SF}_{6}$ for assessing groundwater travel times}

When groundwater residence times are less than 70 years, anthropogenic atmospheric gases such as Chlorofluorocarbons (CFCs) and Sulfur Hexafluoride $\left(\mathrm{SF}_{6}\right)$ can be used for groundwater dating (Cook and Solomon 1997; Cartwright et al. 2017).

Groundwater samples from the Bonifacio aquifer have been analyzed for $\mathrm{CFCs}$ and $\mathrm{SF}_{6}$ (sampling wells P1 and P2 in Figure 1). Groundwater residence times have been estimated between 9 and 50 years in the unconfined aquifer (Santoni et al. 2016a). Note that a later approach linking ${ }^{87} \mathrm{Sr} /{ }^{86} \mathrm{Sr}$ to $\mathrm{CFCs}$ and $\mathrm{SF}_{6}$ made it possible to establish the kinetics of water-rock interactions that support the validity of the obtained groundwater residence times (Santoni et al. 2016b).

\section{Combining analytical and geochemical methods to assess recharge}

Knowledge of groundwater travel time makes it possible to constrain recharge. Equation 1 can be used to calculate one of four parameters when the other three are known: effective porosity, hydraulic conductivity, recharge or groundwater travel time. In Equation 1, the term $t$ can be replaced by the known value of groundwater travel time derived from the analysis of $\mathrm{CFCs}$ and $\mathrm{SF}_{6}$. This time value is the essential parameter 
which makes it possible to adapt the initial Equation 1 by eliminating the need for the original $\mathrm{x}_{\mathrm{i}}$ parameter.

In this study, the travel time of groundwater was obtained from $\mathrm{CFC}$ and $\mathrm{SF}_{6}$ concentrations from groundwater samples taken at two different locations $\left(\mathrm{x}_{1}\right.$ and $\left.\mathrm{x}_{2}\right)$ along the flowline. The difference in age of water $\Delta t$ between these two locations represents the travel time; this value is inserted into Equation 2 as a known variable. Equation 2 is derived from Equation 1 to calculate recharge using the difference in age $\Delta t$ between $\mathrm{x}_{1}$ and $\mathrm{x}_{2}$ (Equation 2):

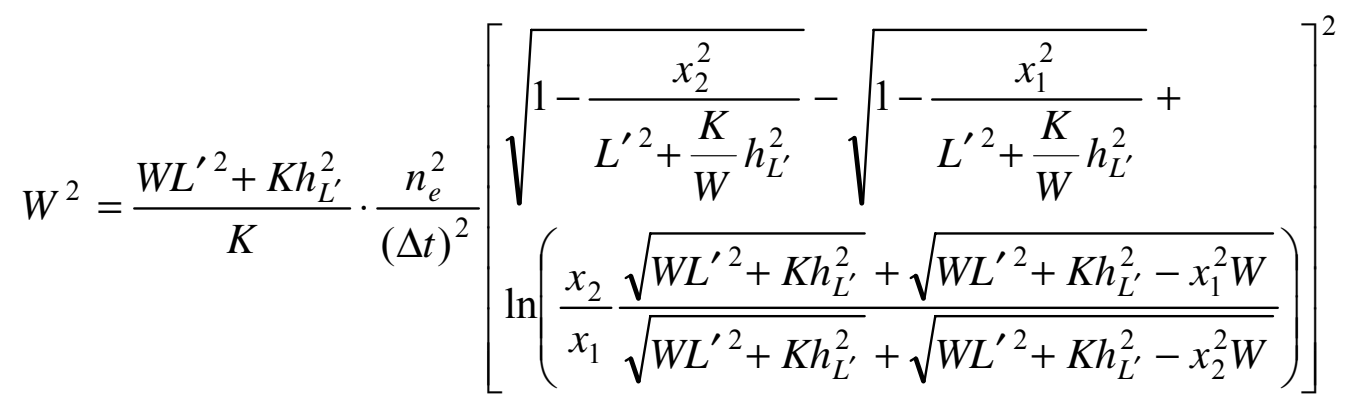

The recharge $W$ can be calculated by solving Equation 2. $W$ cannot be isolated from Equation 2 and in consequence it cannot be directly extracted and calculated. Solving $W$ from Equation 2 requires the use of numerical methods, for example: solvers built into commercial spreadsheets.

\section{Application to the Bonifacio Aquifer}

The configuration of the Bonifacio aquifer makes it appropriate for estimating the groundwater travel time between $\mathrm{P} 1$ and $\mathrm{P} 2$. P1 and P2 positioned along a flow line are shown on the plan view by the A-A' line in Figure 1. The conceptual cross-section is 
shown in Figure 3. Groundwater flows from East to West, is recharged by precipitation and discharges to the Mediterranean Sea near the Bonifacio harbour. The aquifer bottom is $100 \mathrm{~m}$ below sea level at the shore. The aquifer thickness of $100 \mathrm{~m}$ is generally uniform over the extent of the aquifer. The flow in this direction satisfies the DupuitForchheimer flow assumptions where the groundwater flow can be considered steady and unidirectional (1D - flow dimension) within a homogeneous unconfined aquifer bounded by a horizontal substratum. The Eastern boundary of the aquifer consists of a crystalline rock outcrop that is contiguous to the aquifer (Figure 3). This outcrop acts as an impermeable barrier and represents the datum $x=0$ of the cross-section of the aquifer along A-A'. The discharge into the Mediterranean Sea is located 3,176 m from the outcrop (the discharge is at $\mathrm{x}_{\mathrm{L}},=3,176 \mathrm{~m}$ on Figure 3 ). The model considers the assumption that the fresh-saltwater interface has negligible effects on the DupuitForchheimer type flow at a regional scale of several kilometers; therefore, the calculation of groundwater travel times is not significantly affected by saltwater intrusion in this case (Chesnaux and Allen 2008). The two observation piezometers named P1 and P2 and located respectively at $\mathrm{x}_{1}=1,846 \mathrm{~m}$ and $\mathrm{x}_{2}=3,019 \mathrm{~m}$ make it possible to monitor groundwater levels and have been sampled for groundwater residence time evaluation based on analysis of CFCs and $\mathrm{SF}_{6}$.

The groundwater travel time between P1 and P2 is calculated by first determining the groundwater age of each sample using $\mathrm{CFCs}$ and $\mathrm{SF}_{6}$, and then subtracting one groundwater age from another, as presented in Santoni et al. (2016a). Groundwater ages in this aquifer were calculated by Santoni et al. (2016a) to be $t_{1}=9$ years and $t_{2}=39$ 
years, respectively, at P1 (at distance $\mathrm{x}_{1}$ ) and P2 (at distance $\mathrm{x}_{2}$ ). The difference of groundwater ages $\Delta t$ between $\mathrm{x}_{1}$ and $\mathrm{x}_{2}$ is therefore of 30 years, which represents the travel time. Considering a mean hydraulic conductivity of the aquifer of $K=2.5 \times 10^{-4}$ $\mathrm{m} / \mathrm{s}$, an effective porosity of $n_{e}=7 \%, \mathrm{~h}_{\mathrm{L}},=100 \mathrm{~m}$ and computing the positions $\mathrm{x}_{1}$ and $\mathrm{x}_{2}$ in Equation 2 with a travel time of 30 years between $\mathrm{x}_{1}$ and $\mathrm{x}_{2}$, yields a recharge $W=115$ $\mathrm{mm} /$ year. This value is close to the value obtained by Santoni et al. (2018) of 132 $\mathrm{mm} / \mathrm{year}$ using other physical and chemical methods. The total mean annual rainfall is $508 \mathrm{~mm}$ (Santoni et al. 2016c; Santoni et al. 2018), which means that in this study, the recharge is calculated to be $23 \%$, whereas it was calculated to be $26 \%$ in the study of Santoni et al. (2016c) and Santoni et al. (2018).

\section{Sensitivity Analysis}

Santoni et al. (2016a) estimated that the degree of uncertainty regarding the determination of groundwater age difference in the Bonifacio aquifer was \pm 5 years. Thus the travel time in the Bonifacio aquifer is between 25 and 35 years. Figure 4 presents the results of the sensitivity analysis of the calculation of recharge (in terms of $\%$ of precipitation) obtained from Equation 2 as a function of: a- the groundwater age difference $\Delta t$ measured between $\mathrm{x}_{1}$ and $\mathrm{x}_{2} ; \mathrm{b}$ - the hydraulic conductivity of the aquifer; and $\mathrm{c}$ - the effective porosity of the aquifer (Figure 4).

Figure $4 \mathrm{a}$ shows that when the age of groundwater is entered into the equation as 25 and 35 years, the values obtained for recharge are $27 \%$ and $19 \%$, respectively. The sensitivity of Equation 2 to hydraulic conductivity (Figure $4 b$ ) when calculating recharge varies 
between $22 \%$ and $25 \%$ when the hydraulic conductivity varies from $10^{-5}$ to $5 \times 10^{-3} \mathrm{~m} / \mathrm{s}$ (almost 3 orders of magnitude). In the case of the effective porosity, the recharge varies between $15 \%$ and $30 \%$ when the effective porosity varies between $5 \%$ and $10 \%$ (Figure 4c). Considering all the previously stated uncertainties relating to these parameters, an annual recharge value for the aquifer of Bonifacio can be expected to be comprised between $20 \%(100 \mathrm{~mm})$ and $30 \%(150 \mathrm{~mm})$.

Knowledge of the range of mean annual recharge values along the A-A' flow line of the Bonifacio aquifer makes it possible to determine the groundwater travel time from any position $x_{i}$ along the same flow line towards the aquifer outlet using Equation 1. Figure 5 shows the groundwater travel time along the A-A' flow line from $x_{i}$ to the outlet as a function of its distance to the outlet. According to this graph, it appears that a water particle requires a maximum of 200 years to travel from the recharge area (the point of contact between the calcarenites and the granitic bedrock, which act as a no-flow boundary condition) to the outlet (the Mediterranean Sea).

\section{Discussions and Conclusion}

It is important to note that the calculation of recharge using the proposed approach presents certain limitations, due not only to the uncertainty of the parameters that are entered into Equation 2, but also due to the restrictive assumptions that are associated with a Dupuit-Forchheimer flow type aquifer. In consequence, the proposed approach is only applicable to certain specific aquifers that satisfy these conditions. Santoni et al (2016a) also underline and discuss the limitations inherent to the use of CFCs and $\mathrm{SF}_{6}$ 
tracers in the determination of groundwater age. Also, it should be noted that the DupuitForchheimer type flow model considers groundwater flow to be unidimensional, which means that the horizontal component of groundwater velocity is solely considered and the vertical component is neglected. The assumption of a flow that is exclusively horizontal is largely satisfied for laterally extensive, thin aquifers (such as the Bonifacio aquifer), i.e. when $L^{\prime}>>h$.

The calculation of the recharge of aquifers is strongly dependent on the scale that is considered. Some methods are more appropriate in assessing local recharge, while others are more appropriate in calculating regional recharge. The method proposed in this study makes it possible to calculate an average value for regional recharge, but it must be emphasized that local values of recharge within the aquifer may vary. It should be recalled that the proposed methodology assumes homogenous conditions in any studied aquifer, and therefore the accuracy of the results obtained in the case of the Bonifacio aquifer may be affected.

Data about the age of groundwater can be useful not only to determine recharge rates but also to determine effective porosity when both the hydraulic conductivity and the recharge are known. Note that it is usually easier to estimate the effective porosity and the hydraulic conductivity of an aquifer, as these elements can both be determined by simple experimental measurements. It is more difficult to estimate the groundwater travel times or the recharge, as both of these parameters are difficult to determine accurately and with a good degree of confidence using direct measurements.

Because of their cost-effectiveness, immediacy and ease of use, analytical solutions retain their usefulness despite their reliance on certain limitative assumptions. They can provide 
relatively accurate estimates of unknown parameters despite the uncertainties associated with their assumptions. The analytical solution developed by Chesnaux et al. (2005), modified to take into account the added parameter of known groundwater age, has shown itself capable of estimating the recharge of unconfined aquifers under certain conditions. The same approach may be applied in other aquifers as long as the same assumptions and conditions are satisfied.

\section{Acknowledgements}

The authors thank the Editor-in-Chief, Henk Haitjema, the Executive Editor, Robert Schincariol and the Associate Editor, Tomas Perina as well as an anonymous reviewer for their constructive comments. The authors also thank Ms. Josée Kaufmann for editorial collaboration.

\section{References}

-Alamy, Z. and Chiari, J.T. 2010. Renforcement des ressources en eau de la commune de Bonifacio - Forages de recherche d'eau pour l'alimentation en eau potable de la commune - Dossier de fin de travaux, $136 \mathrm{pp}$.

-Bear, J. 1972. Dynamics of fluids in porous media. New York: Dover Publications, Inc.

-Chesnaux, R., Molson, J.W. and Chapuis, R.P. 2005. A closed-form analytical solution for groundwater transit time through unconfined aquifers. Ground Water 43(4): 511-517. 
-Chesnaux, R and Allen, D.M. 2008. Groundwater travel times for unconfined island aquifers bounded by freshwater or seawater. Hydrogeology Journal 16(3): 437-445.

-Chesnaux, R. 2013. Regional recharge assessment in the crystalline bedrock aquifer of the Kenogami Uplands, Canada. Hydrological Sciences Journal 58(2): 1-16.

-Chesnaux, R. 2015. Closed-form analytical solutions for assessing the consequences of sea-level rise on groundwater resources in sloping coastal aquifers. Hydrogeology Journal 23(7): 1399-1413.

-Chesnaux, R. 2016. Closed-form analytical solutions for assessing the consequences of sea-level rise on unconfined sloping island aquifers. Global and Planetary Change 139: 109-115.

-Dörfliger, N., Ferrandini, J., Ferrandini, M. and Mathieu, F. 2001. Caractérisation géométrique et hydrodynamique du causse de Bonifacio (Corse) à partir d'une synthèse des connaissances géologiques et hydrogéologiques par des méthodes géophysiques. BRGM/RP-51860-FR.

-Dupuit, J. 1863. Étude théorique et pratique sur le mouvement des eaux dans les canaux découverts et à travers les terrains perméables. $2^{\text {nd }}$ ed. Paris: Dunod. 
-Forchheimer, P., 1886. Über die Ergiebichkeit von Brunnen-Anlagen und Sickerschlitzen. Zeitschrift des Architectenund Ingenieurs Vereins zu Hannover, 32: 539564.

-Hartmann, A., Gleeson, T., Wada, Y., Wagener, T., 2017. Enhanced groundwater recharge rates and altered recharge sensitivity to climate variability through subsurface heterogeneity. Proceedings of the National Academy of Sciences, 114: 2842-2847.

-Huet, M., Chesnaux, R., Boucher, M.-A. and Poirier, C. 2016. Comparing various approaches for assessing groundwater recharge at a regional scale in the Canadian Shield. Hydrological Sciences Journal 61(12): 2267-2283.

-INOWAS 2017. T13. Travel time through unconfined aquifer. https://wiki.inowas.hydro.tu-dresden.de/t13-travel-time-through-unconfined-aquifer/

-Kinzelbach, W., Aeschbach, W., Alberich, C., Goni, I.B., Beyerle, U., Brunner, P., Chiang, W.H., Rueedi, J., Zoellmann, K., 2002. A survey of methods for groundwater recharge in arid and semi-arid regions. Early warning and assessment Report series, UNEP/DEWA/RS, 2.

-Lerner, D.N., Issar, A.S., Simmers, I., 1990. Groundwater recharge: a guide to understanding and estimating natural recharge, 8. Heise Hannoverpp. 
-Meixner, T., Manning, A.H., Stonestrom, D.A., Allen, D.M., Ajami, H., Blasch, K.W., Brookfield, A.E., Castro, C.L., Clark, J.F., Gochis, D.J., Flint, A.L., Neff, K.L., Niraula, R., Rodell, M., Scanlon, B.R., Singha, K., Walvoord, M.A., 2016. Implications of projected climate change for groundwater recharge in the Western United States. Journal of Hydrology 534: 124-128.

-Orsini, J.-B., Ferrandini, J., Ferrandini, M., Loÿe, M.-D., Pluquet, F., Guennoc, P., Thinon, I., Santiago, M., Reynaud, J.-Y., Oggiano, G., Cherchi, G., Gattaccaca, J., Orrù, P., Puliga, G., Pintus, M., Ulzega, A., 2010. Notice explicative, carte géol. France (1/50 000), feuille Sotta-Bonifacio-Santa-Teresa-di-Gallura (1127), in press. BRGM, Orléans, pp. 258.

-Reynaud, J.-Y., Ferrandini, M., Ferrandini, J., Santiago, M., Thinon, I., André, J.-P., Barthet, Y., Guennoc, P., Tessier, B., 2012. From non-tidal shelf to tide-dominated strait: The Miocene Bonifacio Basin, Southern Corsica. Sedimentology 60: 599-623.

-Santoni, S., Huneau, F., Garel, E., Vergnaud-Ayraud, V., Labasque, T., Aquilina, L., Jaunat, J. and Celle-Jeanton, H. 2016a. Residence time, mineralization processes and groundwater origin within carbonate coastal aquifer with a thick unsaturated zone. Journal of Hydrology 540: 50-63.

-Santoni, S., Huneau, F., Garel, E., Aquilina, L., Vergnaud-Ayraud, V., Labasque, T. and Celle-Jeanton, H. 2016b. Strontium isotopes as tracers of water-rocks interactions, 
mixing processes and residence time indicator of groundwater within the granitecarbonate coastal aquifer of Bonifacio (Corsica, France). Science of Total Environment 573: $233-246$.

-Santoni, S., Huneau, F., Garel, E. and Celle-Jeanton, H. 2016c. Stable isotope composition of rainwater as a proxy to delineate recharge processes to Mediterranean coastal aquifers. $43^{\text {rd }}$ IAH Congress, Environment and Society, Le Corum, Montpellier, France.

-Santoni, S, 2016. Contributions du multitraçage isotopique et géochimique à la compréhension des aquifères côtiers : mise en place d'un modèle de fonctionnement de l'aquifère de Bonifacio (Corse-du-Sud). Ph.D. Thesis, University of Corsica, France.

-Santoni, S, Garel, E., Huneau, F., Celle-Jeanton, H. 2018 Multiple recharge processes to heterogeneous Mediterranean coastal aquifers and implications on recharge rates evolution in time. Journal of Hydrology 559: 669-683.

-Scanlon, B.R., Healey, R.W. and Cook, P.G. 2002. Choosing appropriate techniques for quantifying groundwater recharge. Hydrogeology Journal 10(1): 18-39.

-Scanlon, B.R., Keese, K.E., Flint, A.L., Flint, L.E., Gaye, C.B., Edmunds, W.M., Simmers, I., 2006. Global synthesis of groundwater recharge in semiarid and arid regions. Hydrological Processes 20: 3335-3370 
-Stoeckl, L. and Houben, G. 2012. Flow dynamics and age stratification of freshwater lenses: Experiments and modeling. Journal of Hydrology 458-459: 9-15.

-Vries, J.J., Simmers, I., 2002. Groundwater recharge: an overview of processes and challenges. Hydrogeology Journal 10(1): 5-17. 


\section{Figure captions}

Figure 1: Simplified map of the hydrogeology of the Bonifacio aquifer (modified from Santoni et al. (2016a)) displaying the selected sampling wells and the cross-section along a flow line in the Dupuit-Forchheimer type flow system.

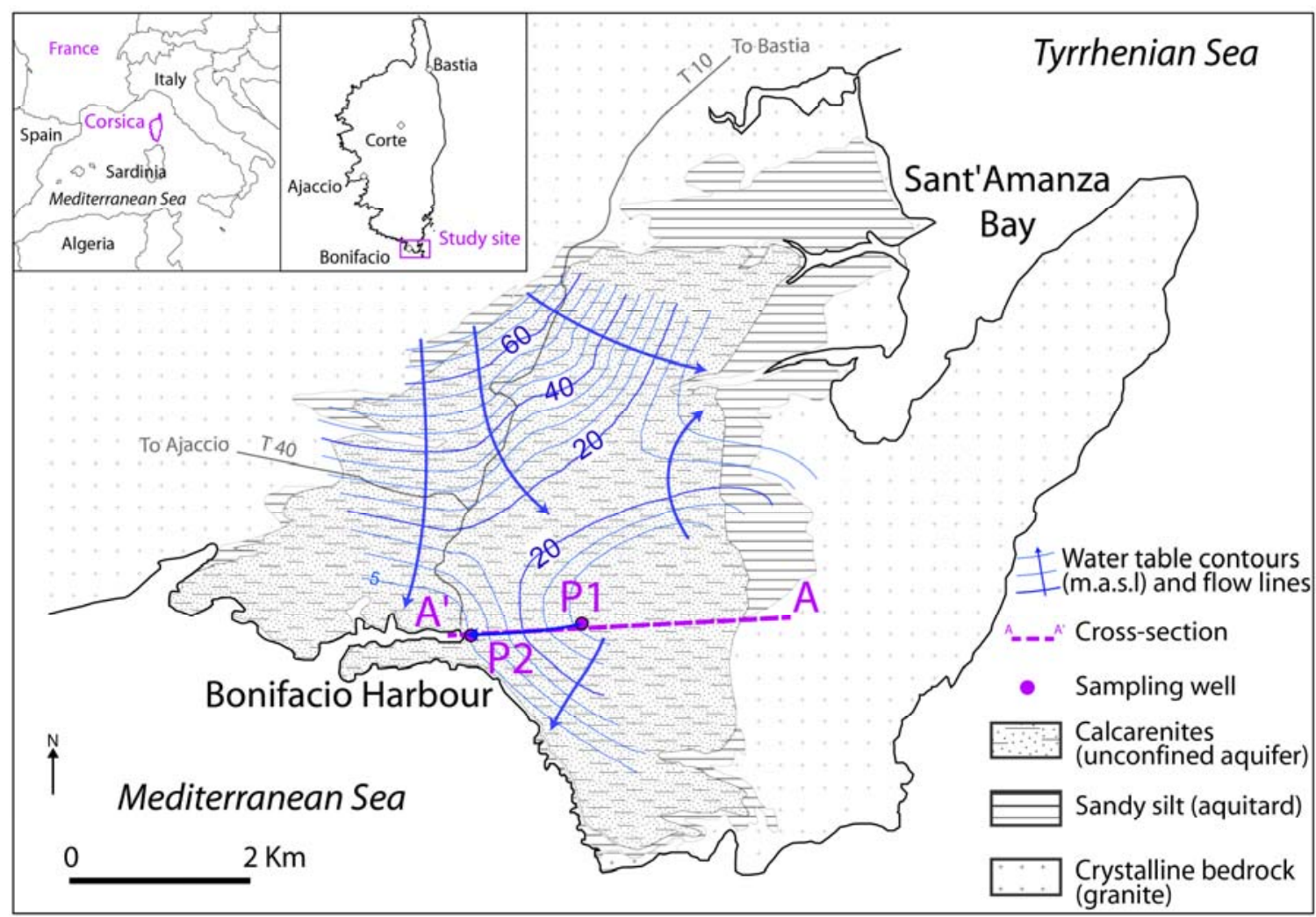


Figure 2: The simplified Dupuit-Forchheimer flow-type system used for developing the general analytical solution of Chesnaux et al. (2005). The left-hand boundary is impermeable (zero $q_{x}$ flux) and flow discharges through the right-hand fixed-head boundary. The travel time is calculated between the two arbitrary points: $x_{i}$ (the departure point at the water table) and $x$ (see Equation 1).

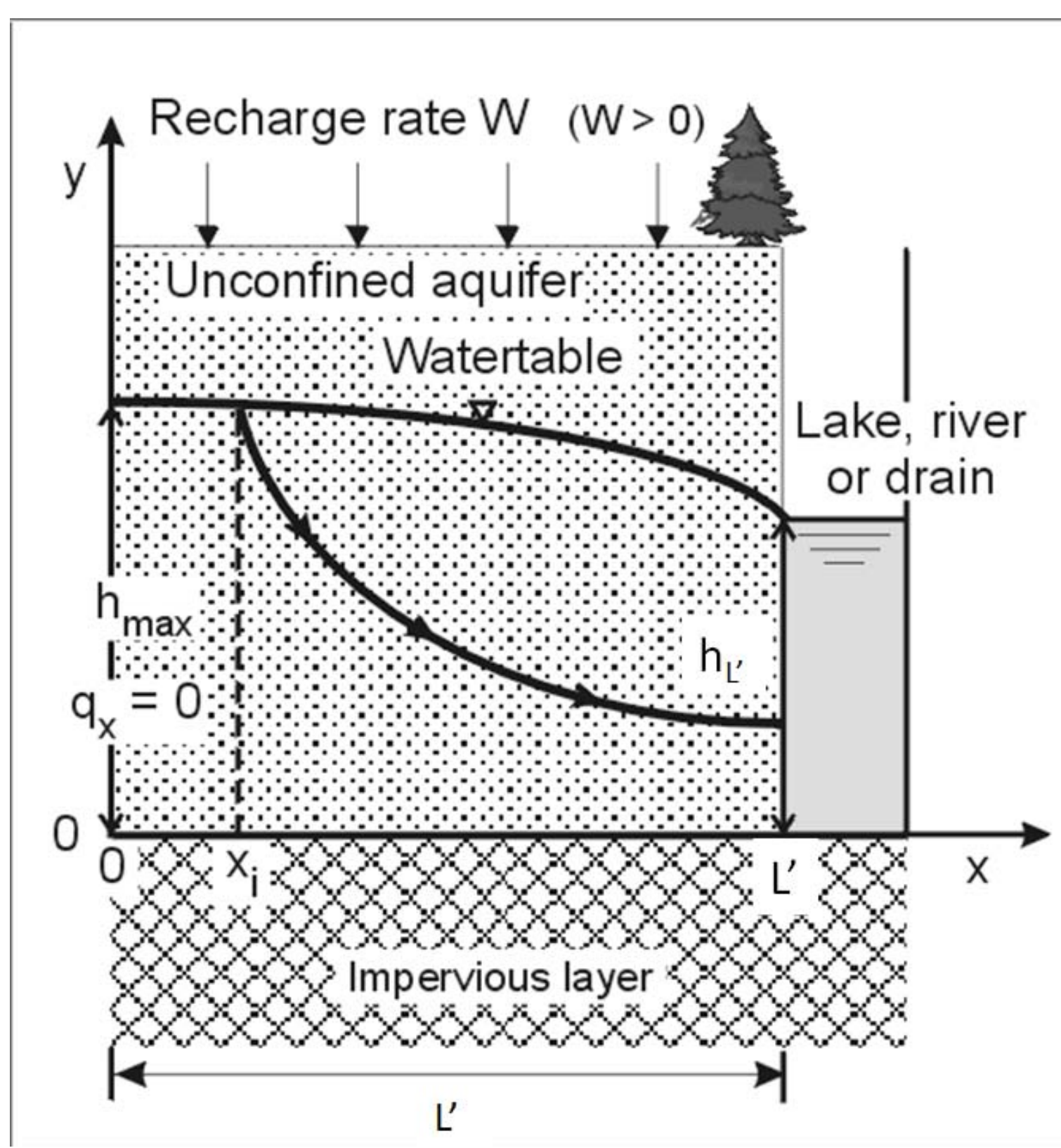


Figure 3: Conceptual hydro-stratigraphic model along the flow line A-A' represented in Figure 1 (modified from Santoni et al. (2016a)).
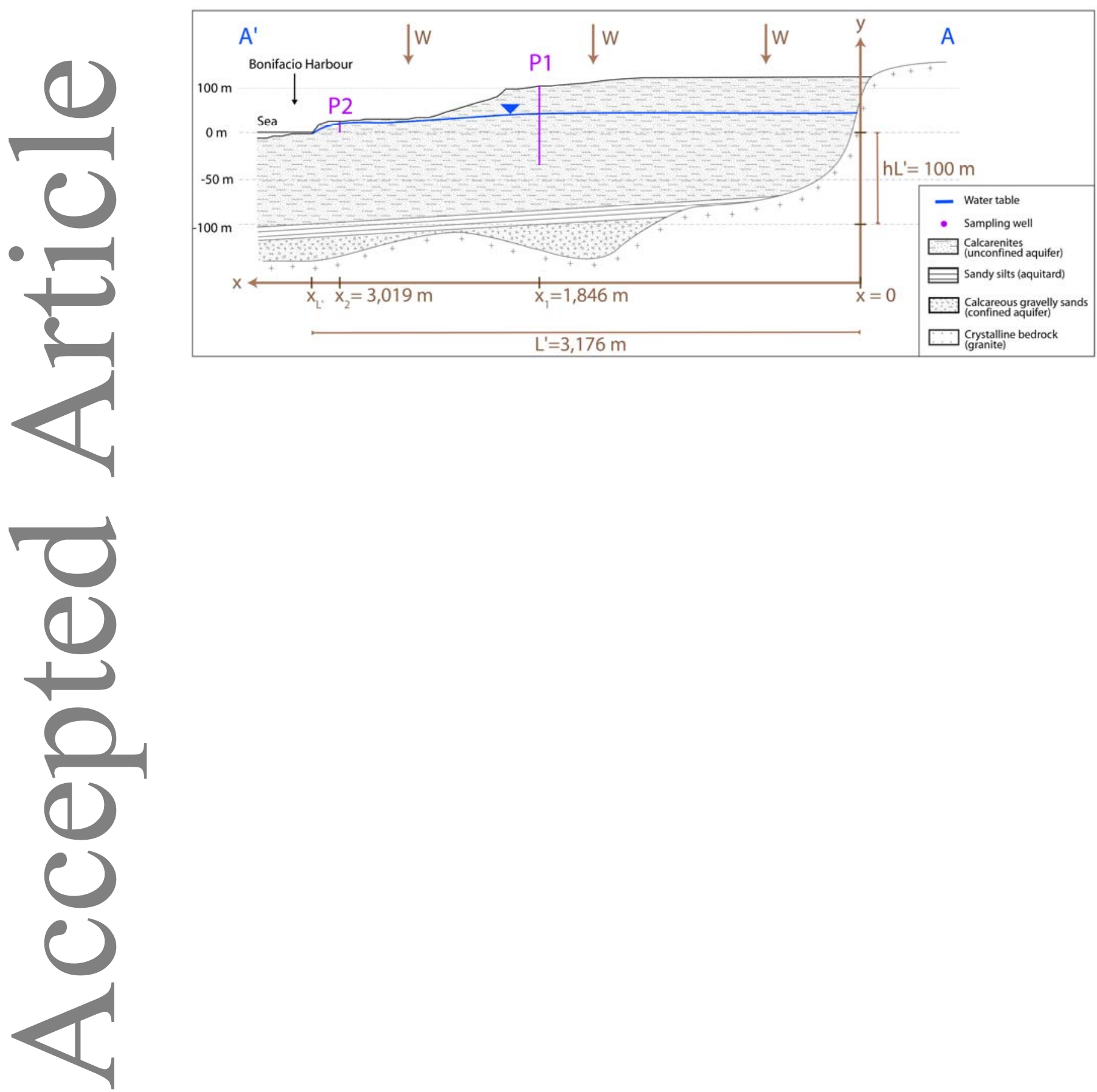
Figure 4: Sensitivity analysis of $\%$ recharge as a function of a) $\Delta t$, b) $K$ and c) $n_{e}$.
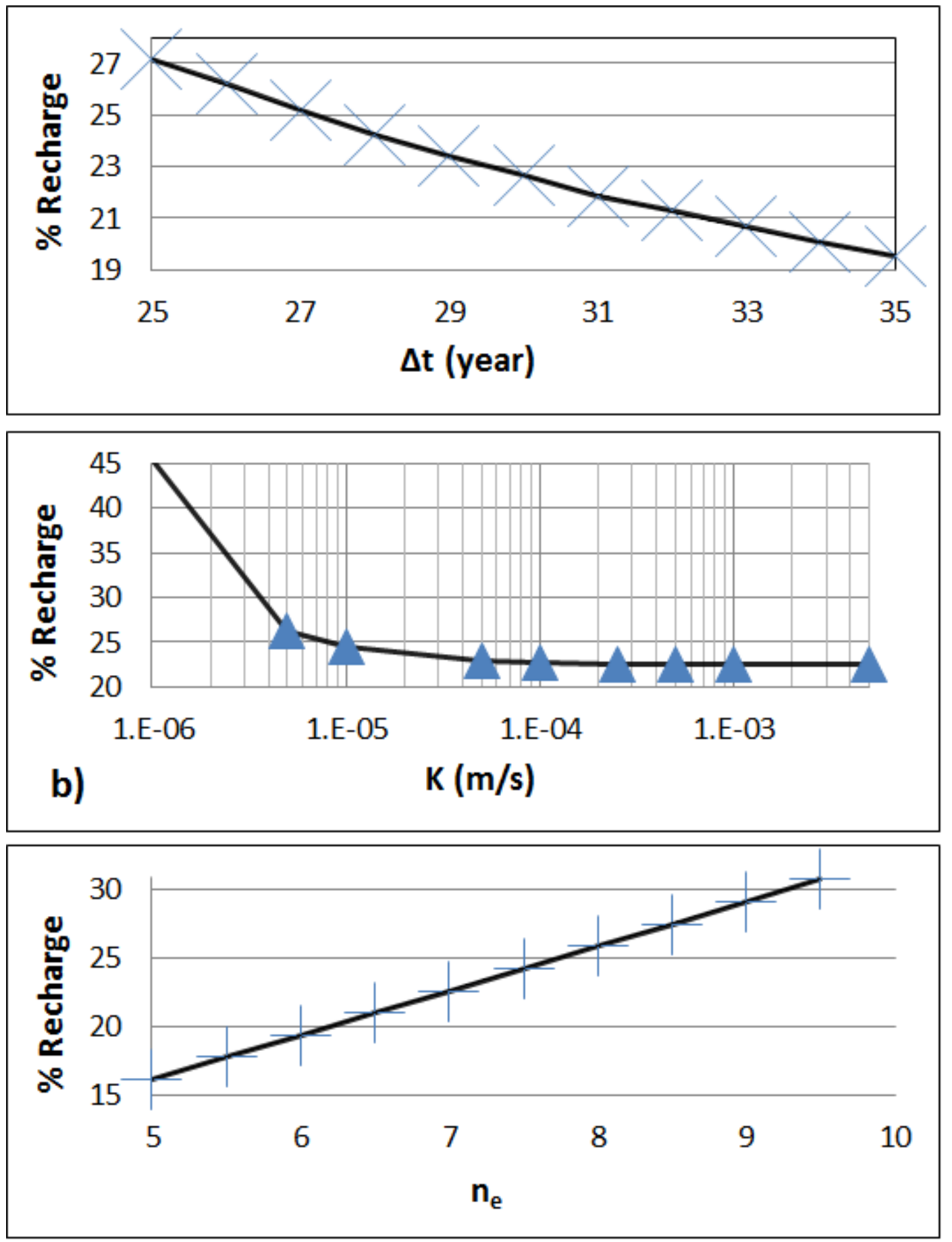
Figure 5: Groundwater travel times from the position of the departure point of the water particle to its discharge into the Mediterranean Sea, using Equation 1.

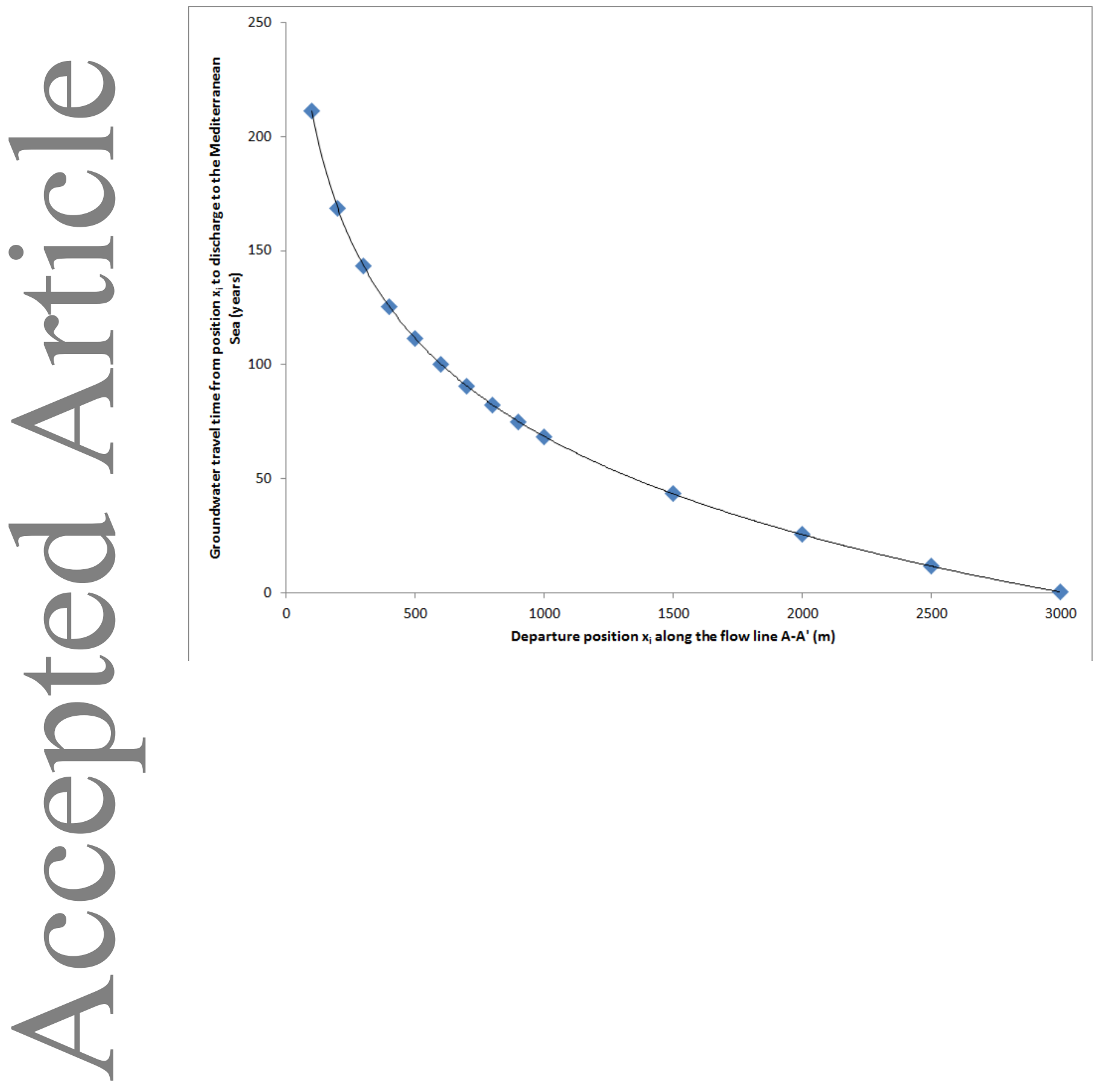

